\title{
A clinical registry of multisystemic presentation of hypovitaminosis $D$ in hospital attendees in Kolkata
}

\author{
Jayati Roy Choudhury', Debasmita Bandyopadhyay², Kheya Mukherjee ${ }^{3}$, \\ Debojyoti Bhattacharjee ${ }^{4}$ \\ ${ }^{1}$ Assistant Professor, ${ }^{4}$ Associate Professor, Department of Biochemistry, IPGME\&R and SSKM Hospital, Kolkata, \\ ${ }^{2}$ Associate Professor, Department of Biochemistry, Bankura Sammilani Medical College and Hospital, Bankura, ${ }^{3}$ Associate \\ Professor, Department of Microbiology, ID \& BG Hospital, Kolkata, West Bengal, India
}

\section{A B S TR A C T}

Background: Vitamin D (Vit D) is a steroid hormone essential for maintaining functional homeostasis in the body. Hypovitaminosis D has been a recognized worldwide problem affecting all age groups and sex. Its prevalence is very high in South Asia. Aims and Objectives: Therefore, this study was aimed to determine the spectrum of presentation of biochemical levels of hypovitaminosis D in Indian population in terms of age, sex, and multisystemic disorders. Materials and Methods: A cross-sectional study carried out on selective study population attending a tertiary care hospital from July 2019 to December 2020 with clinical presentations suspected to arise due to Vit D deficiency. Serum $250 H$ Vit D level was estimated by chemiluminescence method. Data were analyzed using GraphPad Prism 8. Results: Of the study population ( $n=685)$, average serum $25(\mathrm{OH})$ D level in females and males was $24.13 \mathrm{ng} / \mathrm{ml}$ and $28.59 \mathrm{ng} / \mathrm{ml}$, respectively. Significant difference in mean value of Vit $D$ existed in males and females in the 21-40 years age group $(p=0.0048)$. Females in the Vit $D$ deficient group (Vit $D$ level $<20$ ) mostly presented with mastalgia $(20.45 \%)$, low back pain $(17.61 \%)$, and joint pain $(11.36 \%)$. Common clinical presentation in males with Vit D levels less than $20 \mathrm{ng} / \mathrm{ml}$ was diabetes mellitus without CKD (18.34\%), non-diabetic CKD (19.27\%), and low back pain (16.51\%). Conclusion: Low Vit $D$ levels manifest itself as signs and symptoms involving various multisystemic disorders involving different age groups in both sexes. Early recognition and replacement can prevent Access this article online

Website:

http://nepjol.info/index.php/AJMS DOI: 10.3126/ajms.v13i1.39826

E-ISSN: 2091-0576

P-ISSN: 2467-9100

Copyright (c) 2022 Asian Journal of Medical Sciences

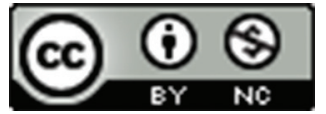

This work is licensed under a Creative Commons Attribution-NonCommercial 4.0 International License. the progress of complications which Vit D deficiency makes us prone to develop.

Key words: Hypovitaminosis D; Clinical manifestations; Multisystemic disorders

\section{INTRODUCTION}

Hypovitaminosis D is prevalent worldwide and is reemerging as a major health problem. ${ }^{1}$

Various studies showed poor Vitamin D (Vit D) status among people irrespective of age, sex, and geography. ${ }^{2}$ India is not an exception. Although India is a tropical country and has adequate sunshine, according to different studies, the prevalence of Vit D deficiency is high in India. ${ }^{3}$ Vit $\mathrm{D}$, which is also called sunshine vitamin, is a member of steroid nuclear hormone superfamily. There are two main forms of Vit D, Vit D3 (cholecalciferol) and Vit D2 (ergocalciferol). More than $90 \%$ of systemic Vit D originates from the skin and around 10\% from food intake. ${ }^{4}$ Cholecalciferol (Vit D3) is the parent compound of the naturally occurring family produced in the skin from 7-dehydrocholesterol on exposure to the ultraviolet B portion of sunlight. Vit D2 may be acquired by ingestion of food such as fish liver oil, fatty fish, egg yolk, and liver. Both Vit D2 and Vit D3 are converted to the active form of Vit D (1,25-dihydroxyvitamin D) 
or calcitriol by successive hepatic and renal hydroxylase enzymes. ${ }^{5}$ Many experts now believe that Vit D or calcitriol should be considered a hormone rather than one of the conventional nutritional vitamins. ${ }^{6}$ The biologically active form of Vit $\mathrm{D}$ is $1,25(\mathrm{OH})_{2} \mathrm{D}$, whereas $25(\mathrm{OH}) \mathrm{D}$ is the main circulating form of Vit $\mathrm{D}$. This active $1,25(\mathrm{OH})_{2} \mathrm{D}$ increases intestinal absorption of calcium and bone resorption and decreases renal excretion of calcium and phosphate. High latitude area, old age, sunscreen use, and skin pigmentation influence production of Vit D3 by skin. Reduced availability is also seen in dietary deficiency, malabsorption syndrome, and bowel resection. Although being a fat-soluble vitamin, high content of fat and meat in diet causes hindrance in its absorption by some mechanism still unclear. Vit $\mathrm{D}$ in meat being present in an insoluble form account for its deficiency among non-vegetarians in both rural and urban diets in Asian subjects in comparison to those perusing a vegetarian meal. ${ }^{7}$ Severe liver or kidney disease is associated with inadequate conversion of Vit $\mathrm{D}$ to its active form. In nephrotic syndrome, there is urinary loss of $25(\mathrm{OH}) \mathrm{D}$ and Vit D-binding protein. ${ }^{5}$ Medications such as phenobarbital, carbamazepine, dexamethasone, nifedipine, spironolactone, clotrimazole, and rifampin induce hepatic p450 enzymes which activate degradation of Vit D. ${ }^{6}$ Circulating concentrations of $1,25(\mathrm{OH})_{2} \mathrm{D}$ are approximately $15-60 \mathrm{pg} / \mathrm{mL}(36-144$ $\mathrm{pmol} / \mathrm{L}$ ) which is about $1 / 1000$ that of $25(\mathrm{OH}) \mathrm{D}$ concentration $(10-50 \mathrm{ng} / \mathrm{mL}$ or $25-125 \mathrm{nmol} / \mathrm{L}$ total 25-hydroxyvitamin D) and are the most significant for therapeutic decisions. ${ }^{8}$ Interest in the non-skeletal effects of Vit D has been increasing since the discovery of $\mathrm{Vit} \mathrm{D}$ receptors and the $1 \alpha$-hydroxylase enzyme in multiple tissues including cells of the pancreas, immune system, macrophages, vascular endothelium, stomach, epidermis, colon, and placenta. ${ }^{\text {? }}$

It is also important to note that subclinical Vit D deficiency is still widely prevalent in both developed and developing countries with a worldwide prevalence of up to 1 billion. ${ }^{10}$ This subclinical Vit D deficiency is associated with osteoporosis, increased risk of falls, and fragility fractures. In recent years, epidemiological and laboratory evidence has documented that $25(\mathrm{OH}) \mathrm{D}$ deficiency is correlated to the onset and progression of many chronic diseases. Many conflicting recent studies are now showing an association between Vit D deficiency and cancer, cardiovascular disease, diabetes, autoimmune diseases, and depression. ${ }^{11}$ Hence, screening for Vit D deficiency in asymptomatic high-risk individuals such as bed redden patients, elderly patients, women with osteoporosis and musculoskeletal disorders, hospitalized patients, patients with chronic kidney disease, chronic liver disease, and patients with malabsorption syndromes is of utmost importance in preventing future complications.
In this background, our aim is to study the prevalence and common types of presentations of Vit D deficiency among 0-80 years aged non-vegetarian people attending a tertiary care hospital in a state of East India so that early preventive and curative measures can be taken in people with minimal symptoms related to Vit $\mathrm{D}$ deficiency.

\section{MATERIALS AND METHODS}

A hospital-based cross-sectional study was designed and conducted. All procedures followed were in accordance with the Helsinki Declaration of 1975 that was revised in $2000 .{ }^{12}$

\section{Study population}

During the period between July 2019 and December 2020 , serum samples were collected from 685 non-vegetarian patients of different age groups between 0 and 80 years attending the outpatient department or in patient department of a tertiary care hospital in a state of East India, with different symptoms which may be related to Vit D deficiency.

\section{Sample size calculation}

About $80 \%$ of adult population in Pakistan, India, and Bangladesh are Vit $\mathrm{D}$ deficient. ${ }^{13}$ Hence, minimum sample size required is $(1.96 \times 1.96 \times 80 \times 20) /(5 \times 5)=246$. We had considered 685 patients and their serum samples were screened for serum vitamin $25(\mathrm{OH}) \mathrm{D}$ level. Although there are different methods and criteria on defining Vit D levels, the criteria Holick proposed has been widely accepted. In this proposal, it is suggested as Vit D deficiency if the level of $25(\mathrm{OH}) \mathrm{D}$ in circulating blood in human is less than or equal to $20 \mathrm{ng} / \mathrm{ml}(50 \mathrm{nmol} / \mathrm{L})$, insufficiency if between 21 and $29 \mathrm{ng} / \mathrm{ml}$, and sufficiency if greater than or equal to $30 \mathrm{ng} / \mathrm{ml}$. These criteria were followed in the study. ${ }^{14}$

Study case population comprised patients with different symptoms suspected to arise due to Vit D deficiency such as diabetes mellitus Type I or Type II with or without nephropathy, chronic kidney disease in non-diabetic patients, musculoskeletal and joint pain, low back pain and hypothyroidism, carcinoma, depression or some other history, and symptoms suggestive of possible vitamin deficiency.

Subjects excluded were patients who received blood transfusions within 1 month before presentation, those already on Vit D supplementations or taking medications known to induce hepatic p450 enzymes which activate degradation of Vit D.

\section{Method of estimation}

Three milliliters of venous blood samples were collected aseptically from patients after $12 \mathrm{~h}$ of fasting in clotted vials. 
Complete clot formation was ensured before centrifugation. Serum was separated after centrifuging at $3000 \mathrm{rpm}$ for $5 \mathrm{~min}$ and was analyzed within $24 \mathrm{~h}$. Serum $25 \mathrm{OH}$ Vit $\mathrm{D}$ level was estimated by chemiluminescence method in ADVIA, Centaur (SIEMENS), which is a competitive immunoassay using direct chemiluminescent technology.

An inverse relationship exists between the amount of Vit D present in the patient sample and the relative light units detected by the system. ${ }^{15}$

\section{Statistical analysis}

Statistical analysis was done by GraphPad Prism 8. Mean value of different groups was calculated. Significance of the difference between means was detected using unpaired t-test and calculating the $\mathrm{P}$-value $(\mathrm{P}<0.05$ was considered as statistically significant).

\section{RESULTS}

Of the study population ( $\mathrm{n}=685), 367(53.58 \%)$ were female and $318(46.42 \%)$ were male patients with mean age of $40.44 \pm 14.96$ years and $45.08 \pm 18.69$ years, respectively. All the participants were divided into four age groups (0-20 years: Group 1, 21-40 years: Group 2, 41-60 years: Group 3, and 61-80 years: Group 40). Average serum $25(\mathrm{OH}) \mathrm{D}$ level in females being $24.13 \mathrm{ng} / \mathrm{ml}$. Among them, $47.95 \%$ had serum $25(\mathrm{OH}) \mathrm{D}$ level $<20 \mathrm{ng} / \mathrm{ml}, 28.61 \% \mathrm{had}$ serum 25(OH)D level between $20 \mathrm{ng} / \mathrm{ml}$ and $30 \mathrm{ng} / \mathrm{ml}$, and $23.43 \%$ had serum $25(\mathrm{OH}) \mathrm{D}$ level $>30 \mathrm{ng} / \mathrm{ml}$ (Table 1$)$.

Among 318 males, average Vit D level was $28.59 \mathrm{ng} / \mathrm{ml}$. Among them, 109 (34.17\%) had serum 25(OH)D level $<20 \mathrm{ng} / \mathrm{ml}, 95$ (29.87\%) had serum 25(OH)D level between $20 \mathrm{ng} / \mathrm{ml}$ and $30 \mathrm{ng} / \mathrm{ml}$, and 114 (35.84\%) had serum $25(\mathrm{OH}) \mathrm{D}$ level $>30 \mathrm{ng} / \mathrm{ml}$ (Table 1$)$.

There was no significant difference in mean serum $25(\mathrm{OH})$ $\mathrm{D}$ levels between in males and females of Groups 1, 3, and $4(\mathrm{P}=0.24,0.39$, and 0.30 , respectively). However, there was a significant difference in mean value in males and females in the $21-40$ years age group $(\mathrm{P}=0.0048)$ (Table 2). ${ }^{16-19}$

Among females in the Vit D deficient group (Vit D level $<20)$, mostly presented with mastalgia $36(20.45 \%)$, low back pain 31 (17.61\%), joint pain $20(11.36 \%)$, or CKD 17 (9.66\%) whereas those in the Vit D insufficient group, mostly presented with low back pain 25 (23.81\%) and mastalgia 17 (16.19\%) (Table 3).

Among 109 males with Vit D levels less than $20 \mathrm{ng} / \mathrm{ml}$, $20(18.34 \%)$ presented with diabetes mellitus without CKD, $21(19.27 \%)$ with non-diabetic CKD, 18 (16.51\%) with low back pain, and $17(15.59 \%)$ with joint pain whereas among 95 Vit D insufficient patients (Vit D level 20-30), mostly presented with low back pain 18 (18.95\%), generalized body ache 17 (17.89\%), or CKD 18 (18.95\%) (Table 3).

\section{DISCUSSION}

In our study, 685 patients were screened and among them, $285(41.61 \%)$ are Vit D deficient $(<20 \mathrm{ng} / \mathrm{ml})$. Other studies showed that the prevalence of Vit D deficiency is prevalent worldwide, both in sunshine deficient and sunshine sufficient countries. India being a tropical country has adequate sunshine. In spite of this, the prevalence of Vit $\mathrm{D}$ deficiency is high in India. ${ }^{3}$

In our study, average serum $25(\mathrm{OH}) \mathrm{D}$ level in males and females was $28.59 \mathrm{ng} / \mathrm{ml}$ and $24.13 \mathrm{ng} / \mathrm{ml}$, respectively. Compared to males $(34.17 \%)$, quite a high percentage of females $(47.95 \%)$ had serum $25(\mathrm{OH}) \mathrm{D}$ level less than $20 \mathrm{ng} / \mathrm{ml}$ (Table 1). Review article by Schoor et al., shows that serum $25(\mathrm{OH}) \mathrm{D}$ levels are suboptimal not only in specific risk groups but also in healthy adults in many countries. Especially, in the Middle-East and Asia,

\section{Table 1: Age group wise Vit D status in males and females}

\begin{tabular}{|c|c|c|c|c|}
\hline \multicolumn{5}{|c|}{ Vitamin D level (ng/dl) } \\
\hline Male & $0-20$ years $(n=46)$ & $21-40$ years $(n=66)$ & $41-60$ years $(n=140)$ & $>60$ years $(n=66)$ \\
\hline Female & $0-20$ years $(n=35)$ & $21-40$ years $(n=148)$ & $41-60$ years $(n=160)$ & $>60$ years $(n=24)$ \\
\hline \multicolumn{5}{|c|}{ Vit $\mathrm{D}<20 \mathrm{ng} / \mathrm{ml}$} \\
\hline Male & $13(28.26 \%)$ & $21(31.82 \%)$ & $50(35.71 \%)$ & $19(28.78 \%)$ \\
\hline Female & $18(51.42 \%)$ & $86(58.10 \%)$ & $73(45.63 \%)$ & $10(41.67 \%)$ \\
\hline \multicolumn{5}{|c|}{ Vit D 20-30 (ng/ml) } \\
\hline Male & $20(43.48 \%)$ & $22(33.33 \%)$ & $48(34.29 \%)$ & $16(24.24 \%)$ \\
\hline Female & $9(25.71 \%)$ & $40(27.03 \%)$ & $45(28.13 \%)$ & $9(37.5 \%)$ \\
\hline \multicolumn{5}{|c|}{ VitD>30 (ng/ml) } \\
\hline Male & $13(28.26 \%)$ & $23(34.85 \%)$ & $42(30 \%)$ & $31(46.97 \%)$ \\
\hline Female & $8(22.86 \%)$ & $22(14.86 \%)$ & $42(26.25 \%)$ & $5(20.83 \%)$ \\
\hline
\end{tabular}


Table 2: Comparison of serum Vitamin D levels in males and females of different age groups in reference to community-based study results on Vitamin $\mathrm{D}$ deficiency

\begin{tabular}{lccc}
\hline Age group $(\mathbf{n g} / \mathrm{dl})$ & Male $($ mean \pm SD) $(\mathbf{n g} / \mathbf{m l})$ & Female $(\mathbf{m e a n} \pm \mathbf{S D})(\mathbf{n g} / \mathbf{m l})$ & P-value \\
\hline 0-20 years $(18.06 \pm 8.17) 16$ & $26.14 \pm 12.55$ & $22.53 \pm 14.77$ & 0.2385 \\
21-40 years $(17 \pm 9.41) 17$ & $30.15 \pm 21.41$ & $22.50 \pm 16.54$ & 0.0048 \\
$41-60$ years $(24.7 \pm 7.49) 18$ & $27.35 \pm 18.97$ & $25.59 \pm 16.25$ & 0.3913 \\
$61-80$ years $(19.3 \pm 0.54) 19$ & $31.39 \pm 18.76$ & $26.73 \pm 19.44$ & 0.3048 \\
\hline
\end{tabular}

*Concentration levels of serum 25 -hydroxyvitamin D and Vitamin D deficiency among children and adolescents of India: A descriptive cross-sectional study

Table 3: Percentages of different types of presentation in males with different Vitamin D levels

\begin{tabular}{|c|c|c|c|c|}
\hline Key & Sex & Vitamin $\mathrm{D}<20 \mathrm{ng} / \mathrm{ml}(\%)$ & Vitamin D 20-30 ng/ml (\%) & Vitamin D>30 ng/ml (\%) \\
\hline \multirow[t]{2}{*}{ Total number of subjects } & Male & $109(34.17)$ & $95(29.87)$ & $114(35.85)$ \\
\hline & Female & $176(47.96)$ & $105(28.61)$ & $86(23.43)$ \\
\hline \multirow[t]{2}{*}{ DM } & Male & $20(18.34)$ & $6(6.32)$ & $9(7.89)$ \\
\hline & Female & $15(8.52)$ & $12(11.43)$ & $12(13.9)$ \\
\hline \multirow[t]{2}{*}{ JP } & Male & $17(15.59)$ & $5(5.26)$ & $10(8.77)$ \\
\hline & Female & $20(11.36)$ & $12(11.43)$ & $6(6.98)$ \\
\hline LBP & Male & $18(16.51)$ & 18 (18.95) & $23(20.18)$ \\
\hline \multirow[t]{2}{*}{ CKD } & Male & 21 (19.27) & $18(18.95)$ & $21(18.42)$ \\
\hline & Female & $17(9.66)$ & $12(11.43)$ & $10(11.62)$ \\
\hline \multirow[t]{2}{*}{$\mathrm{DM}+\mathrm{CKD}$} & Male & $8(7.34)$ & $6(6.32)$ & $6(5.26)$ \\
\hline & Female & $11(6.25)$ & $6(5.7)$ & $11(12.79)$ \\
\hline \multirow[t]{2}{*}{ CA } & Male & $2(1.83)$ & 0 & 0 \\
\hline & Female & $4(2.27)$ & $1(0.95)$ & $2(2.32)$ \\
\hline Hypothyroid & Male & $3(2.75)$ & $6(6.32)$ & $1(0.88)$ \\
\hline Mastalgia & Female & $36(20.45)$ & 17 (16.19) & $11(12.79)$ \\
\hline \multirow[t]{2}{*}{ Non-specific symptoms } & Male & $11(10.09)$ & $18(18.94)$ & $25(21.93)$ \\
\hline & Female & $15(8.5)$ & $4(3.8)$ & $2(2.32)$ \\
\hline
\end{tabular}

Vit D deficiency in adults is highly prevalent. ${ }^{1}$ Various other studies also showed poor Vit D status irrespective of age, sex, and location. ${ }^{2}$

There is also no significant difference in mean serum $25(\mathrm{OH}) \mathrm{D}$ levels between males and females of $0-20$ years, 41-60 years, and 61-80 years age groups. However, significant difference was apparent in mean value in males and females in the $21-40$ years age group (Table 2). The cause of low values in females can be associated to poor exposure to sunlight, use of sunscreen creams, increased physiological Vit D demand in reproductive age group, and lower intake of Vit D rich foods in Indian females between 21 and 40 years of age. In males with $25(\mathrm{OH}) \mathrm{D}$ levels less than $20 \mathrm{ng} / \mathrm{ml}, 19.27 \%$ presented with non-diabetic CKD, $18.34 \%$ presented with diabetes mellitus without CKD, and $16.51 \%$ with low back pain whereas Vit D insufficient patients $(25(\mathrm{OH}) \mathrm{D}$ levels: 20-30 $\mathrm{ng} / \mathrm{ml})$, mostly presented with LBP (18.95\%), CKD (18.95\%), and JP (17.89\%). Females in the Vit D deficient group mostly presented with complaints of mastalgia (20.45\%), LBP (17.61\%), and JP (11.36\%). Most common clinical presentations in Vit D insufficient group were LBP (23.81\%) and mastalgia 17 (16.19\%). JP was a distant third form of presentation along with DM and
CKD (11.43\%) (Table 3). The results indicate that Indian subject with hypovitaminosis presents with varied clinical manifestations in different sex. While chronic metabolic disorders such as DM and CKD are associated with low Vit D in males, mastalgia and musculoskeletal disorders are common clinical association in females. Recent studies have confirming reports on hypovitaminosis $\mathrm{D}$ which is association with progression of CKD and its complications, particularly the cardiovascular events. The prevalence of hypovitaminosis D amongst 135 CKD patients in Nigeria was found to be $82.2 \%$ compared to $45.2 \%$ in the control participants $(\mathrm{P}<0.001)$. Serum Vit $\mathrm{D}$ correlated inversely with the left ventricular mass index, urine albumincreatinine ratio, and systolic blood pressure and positively with estimated glomerular filtration rate. ${ }^{20}$ Meta-analysis of 14 studies involving 2602 patients had suggested high prevalence of hypovitaminosis $\mathrm{D}$ in patients with LBP. This provides the caregivers a chance to screen and supplement Vit $D$ as a therapeutic adjunct in the management of LBP patients. ${ }^{21}$ A rural population-based study related to hypovitaminosis D and effect of Vit D supplementation in Type 2 diabetes mellitus patients had revealed a rural prevalence of low Vit D level. Significant improvements in $\mathrm{HbA1c}$ after treatment with Vit D had suggested that Vit D supplementation could improve glycemic status in 
Type 2 diabetes mellitus patients. ${ }^{22}$ Retrospective analysis of 71 non-osteomalacia patients in Mumbai, India, with low Vit D levels presented with many non-specific symptoms such as backache, body ache, leg pain, and thigh pain. It revealed a widespread state of subclinical Vit D characterized by non-specific musculoskeletal symptoms often masquerading an underlying rheumatic disorder. ${ }^{23}$ Similar to this study population, pilot study on nonCaucasians in the United Kingdom has shown positive correlation between Vit D deficiency and non-cyclical mastalgia. Improvement of symptoms was observed in majority of these patients' following supplementation of Vit D. Thus, the role of Vit D in regulation of estrogenprogesterone internal milieu is evolving. ${ }^{24}$

There has been accumulating evidence indicating that Vit $\mathrm{D}$ may provide great health benefits. Indeed, it has been shown that Vit D deficiency not only causes bone and mineral disturbances but also may increase the risk of many common chronic diseases. The interest in the nutritional status of Vit D of CKD patients has been renewed after the recognition that low circulating levels of 25-hydroxyvitamin D can contribute to the development of secondary hyperparathyroidism. The study has its own limitations in terms being a single-center hospital-based study. The underlying mechanism for all of these presentations has not been elucidated. However, the study is an eye opener to the fact that a vast spectrum of clinical presentation accompanies hypovitaminosis $\mathrm{D}$. The results when projected to general population will pave wave for population based epidemiological studies. Since primarily symptomatic patients were included, the study has missed to include asymptomatic or subclinical individuals who were Vit $\mathrm{D}$ deficient.

\section{CONCLUSION}

Most of the Indian population specially those living in eastern parts of India live in areas with adequate sunlight throughout the year and are expected to have adequate Vit $\mathrm{D}$, still Vit $\mathrm{D}$ deficiency is highly prevalent. Furthermore, it is quite underdiagnosed and undertreated nutritional deficiency manifesting in different forms. Hence, it can be concluded that if more regular screening is done of serum Vit $\mathrm{D}$ in symptomatic patients irrespective of age, a number of complications can be reduced or cured by diagnosing Vit $\mathrm{D}$ deficient patients and treating them with Vit D by therapeutic supplementation.

\section{ACKNOWLEDGMENTS}

The authors wish to acknowledge all the technical assistants in the department of biochemistry for all their contribution in compilation of raw data.

\section{REFERENCES}

1. van Schoor NM and Lips P. Worldwide Vitamin D status. Best Pract Res Clin Endocrinol Metab. 2011;25(4):671-680.

2. Aparna P, Muthathal S, Nongkynrih B and Gupta SK. Vitamin D deficiency in India. J Family Med Prim Care. 2018;7(2):324-330. https://doi.org/10.4103/jfmpc.jfmpc_78_18

3. Babu US and Calvo MS. Modern India and the Vitamin D dilemma: Evidence for the need of a national food fortification program. Mol Nutr Food Res. 2010;54(8):1134-1147. https://doi.org/10.1002/mnfr.200900480

4. Holick MF. Sunlight and Vitamin D for bone health and prevention of autoimmune diseases, cancers, and cardiovascular disease. Am J Clin Nutr. 2004;80(6):1678-1688.

https://doi.org/10.1093/ajcn/80.6.1678s

5. Risteli J, Winter WE, Kleerekoper M and Risteli M. Vitamin D and its metabolites. In: Burtis CA, Ashwood ER, Bruns DE and Barbara G, editors. In: Tietz Fundamentals of Clinical Chemistry. $7^{\text {th }}$ ed. Sawyer, St. Louis, Missouri: Saunders, Elsevier; 2015. p. 1841-1846.

https://doi.org/10.1373/clinchem.2007.101378

6. Gröber $U$ and Kisters $K$. Influence of drugs on Vitamin D and calcium metabolism. Dermatoendocrinology. 2012;4(2):158-166. https://doi.org/10.4161/derm.20731

7. Baig JA, Sheikh SA, Islam I and Kumar M. Vitamin D status among vegetarians and non-vegetarians. J Ayub Med Coll Abbottabad. 2013;25(1-2):152-155.

8. Misra M, Pacaud D, Petryk A, Collett-Solberg PF and Kappy M. Drug and therapeutics committee of the Lawson Wilkins pediatric endocrine society. Vitamin $\mathrm{D}$ deficiency in children and its management: Review of current knowledge and recommendations. Pediatrics. 2008;122(2):398-417.

https://doi.org/10.1542/peds.2007-1894

9. Plum LA and DeLuca HF. The functional metabolism and molecular biology of Vitamin D action. In: Holick MF, editor. Vitamin D: Physiology, Molecular Biology, and Clinical Applications. $2^{\text {nd }}$ ed. New York: Humana Press; 2010. p. 61-97. https://doi.org/10.1007/978-1-60327-303-9_3

10. Nair R, Maseeh A. Vitamin D: The "Sunshine" vitamin. J Pharmacol Pharmacother. 2012;3(2):118-126. https://doi.org/10.4103/0976-500X.95506

11. Holick MF. Vitamin D: Important for prevention of osteoporosis, cardiovascular heart disease, Type 1 diabetes, autoimmune diseases, and some cancers. South Med J. 2005;98(10):1024-1027.

https://doi.org/10.1097/01.smj.0000140865.32054.db

12. Carlson RV, Boyd KM and Webb DJ. The revision of the declaration of Helsinki: Past, present and future. $\mathrm{Br} \mathrm{J}$ Clin Pharmacol. 2004;57(6):695-713.

https://doi.org/10.1111/j.1365-2125.2004.02103.x

13. Palacios $C$ and Gonzalez L. Is Vitamin D deficiency a major global public health problem? J Steroid Biochem Mol Biol. 2014;144:138-145.

https://doi.org/10.1016/j.jsbmb.2013.11.003

14. Dawson-Hughes B, Heaney RP, Holick MF, Lips P, Meunier PJ and Vieth R. Estimates of optimal Vitamin D status. Osteoporos Int. 2005;16(7):713-716.

https://doi.org/10.1007/s00198-005-1867-7

15. Rollins G. Vitamin D Testing-what's the right answer? Labs grapple with confusing analytics, evidence. Clin Lab News. 2009;35(7):1-7. 
16. Shivane VK, Sarathi V, Lila AR, Bandgar T, Joshi SR, Menon PS, et al. Peak bone mineral density and its determinants in an Asian Indian population. J Clin Densitom. 2012;15:152-158. https://doi.org/10.1016/j.jocd.2011.12.007

17. Multani SK, Sarathi V, Shivane V, Bandgar TR, Menon PS and Shah NS. Study of bone mineral density in resident doctors working at a teaching hospital. J Postgrad Med. 2010;56(2):65-70.

https://doi.org/10.4103/0022-3859.65272

18. Maisnam I, Dutta D, Mukhopadhyay S and Chowdhury S. Lean mass is the strongest predictor of bone mineral content in Type2 diabetes and normal individuals: An Eastern India perspective. J Diabetes Metab Disord. 2014;13(1):90. https://doi.org/10.1186/s40200-014-0090-5

19. Suryanarayana P, Arlappa N, Sai Santhosh V, Balakrishna N, Lakshmi Rajkumar P, Prasad U, et al. Prevalence of Vitamin D deficiency and its associated factors among the urban elderly population in Hyderabad metropolitan city, South India. Ann Hum Biol. 2018;45(2):133-139.

https://doi.org/10.1080/03014460.2018.1425479

20. Abimbola B, Segun O, Sunday O, Taslim A, Abiola Y, Olaide A, et al. The prevalence, pattern and predictors of hypovitaminosis $D$ in patients with chronic kidney disease: A study in a tertiary care hospital in Nigeria. Kidney Int Rep. 2021;6(4):105-106. https://doi.org/10.1016/j.ekir.2021.03.266

21. Bansal D, Boya CS, Vatte R and Ghai B. High prevalence of hypovitaminosis $D$ in patients with low back pain: Evidence from meta-analysis. Pain Physician. 2018;21(4):E389-E399. https://doi.org/10.36076/ppj.2018.4.e389

22. Janakiraman $S$ and Subramanian G. Hypovitaminosis D and effect of Vitamin D supplementation in Type 2 diabetes mellitus: A rural population-based study. Int J Adv Med. 2019;6(4):1293-1298. https://doi.org/10.18203/2349-3933.ijam20193288

23. Kanekar A, Sharma M and Joshi VR. Vitamin D deficiency-a clinical spectrum: Is there a symptomatic nonosteomalacic state? Int J Endocrinol. 2010;2010:521457. https://doi.org/10.1155/2010/521457

24. Li E, Rizkalla N, Rai S, Vishwanath L and Sintler M. Vitamin D supplementation in the treatment of non-cyclical breast pain. J Pain Relief 2018;7(5):330. https://doi.org/10.4172/2167-0846.1000330

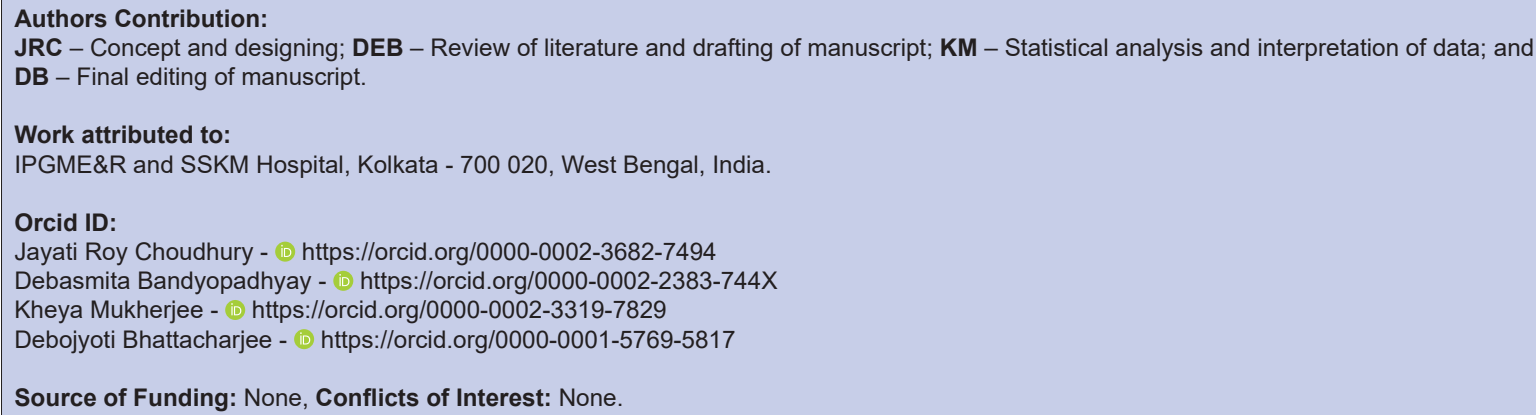

